\title{
A redescription of Trichosurolaelaps dixous Domrow, 1972 (Acari: Laelapidae), from Trichosurus cunninghami (Marsupialia: Phalangeridae) from southern Australia
}

\author{
Jasmin Hufschmid $^{1,2}$, Ian Beveridge ${ }^{1}$, Kathrine Ann Handasyde ${ }^{2}$ and David Michael Spratt ${ }^{3}$ \\ ${ }^{1}$ Faculty of Veterinary Science, University of Melbourne, Veterinary Clinical Centre, Werribee VIC 3030, Australia; \\ ${ }^{2}$ Department of Zoology, University of Melbourne, Parkville VIC 3010, Australia; \\ ${ }^{3}$ CSIRO, Sustainable Ecosystems, Canberra ACT 2601, Australia
}

Key words: Trichosurolaelaps dixous, Trichosurolaelaps crassipes, Trichosurus cunninghami, Trichosurus vulpecula, ectoparasites, Acari, Laelapidae

\begin{abstract}
The adults of Trichosurolaelaps dixous Domrow, 1972 are redescribed from a population of Trichosurus cunninghami Lindenmayer, Dubach et Viggers, 2002 in south-eastern Australia. The nymphal stages are described for the first time. Morphologically, T. dixous is similar to Trichosurolaelaps crassipes Womersley, 1956. Morphological differences between the prefemale deutonymphs and adult females of the two mite species are the presence of a single large ventral spur on tibia I of $T$. dixous. Males of $T$. dixous could not be distinguished from $T$. crassipes morphologically and the idiosomal length of male $T$. dixous was variable $(475-683 \mu \mathrm{m})$. Protonymphs of the two mite species differed only in size, with that of $T$. dixous being larger. Although T. crassipes was prevalent in a sympatric population of Trichosurus vulpecula and has been reported from other populations of T. cunninghami in southern Australia, it was never recovered from the population of T. cunninghami studied.
\end{abstract}

There are three species of brushtail possums: the common brushtail possum (Trichosurus vulpecula Kerr), the short-eared possum (T. caninus Ogilby) and the mountain brushtail possum ( $T$. cunninghami Lindenmayer, Dubach et Viggers). Trichosurus vulpecula inhabits much of mainland Australia and Tasmania (Kerle et al. 1991), as well as New Zealand, where it is an introduced pest species (Pracy 1962). The more northern $T$. caninus and the more southern T. cunninghami have more restricted distributions at higher elevations along the east coast of Australia (Bennett et al. 1991, Van Der Ree et al. 2004).

Lumbo-sacral dermatitis ("rumpwear"), which is characterised by coat and skin damage in the rump region of affected animals, is a very common disease in brushtail possums (Trichosurus spp.) in Australia, possibly caused by a reaction to haematophagous ectoparasites, including Trichosurolaelaps spp. (Munday 1966, Presidente 1978, 1984, Hemsley and Canfield 1994). Skin-surface inhabiting Trichosurolaelaps spp. are among the most prevalent ectoparasites of Trichosurus spp. populations in Australia and New Zealand (Sweatman 1962, Presidente 1978, Clark 1993, Viggers and Lindenmayer 2004). The two congeneric mites Trichosurolaelaps dixous Domrow, 1972 and Trichosurolaelaps crassipes Womersley, 1956 are morphologically very similar, making differentiation of the two species difficult. In addition, the immature life-cycle stages of $T$. dixous, unlike those of $T$. crassipes (see Domrow 1979, Clark 1995), have not been described previously. Trichosurolaelaps dixous has been reported from T. caninus (Domrow 1972) and T. cunninghami (Viggers and Lindenmayer 2004), with the prevalence of $T$. dixous in populations of possums varying from $23 \%$ to $91 \%$ for two populations of $T$. cunninghami at Cambarville and Bellbridge (Victoria) and $29 \%$ to $94 \%$ for five populations of $T$. caninus from New South Wales and Queensland (Viggers 1996).

In order to facilitate identification of T. dixous and to reduce possible confusion with $T$. crassipes, a redescription of $T$. dixous, based on scanning electron and light microscopy, was undertaken. A description of its nymphal stages and morphological features to distinguish the pre-female deutonymph and adult female of $T$. dixous from $T$. crassipes are included.

\section{MATERIALS AND METHODS}

Trichosurus cunninghami $(\mathrm{n}=398)$ and $T$. vulpecula $(n=30)$ were captured on eight field trips over two years at Boho South, Victoria, south-eastern Australia (36² ${ }^{\prime}$ 'S, $\left.145^{\circ} 45^{\prime} \mathrm{E}\right)$, using wire cage traps. Possums were sedated with zolazepam/tiletamine (Zoletil ${ }^{\circledR}$ Virbac, France) for collection of ectoparasites of the rump region. A $4 \times 4 \mathrm{~cm}$ patch of fur was shaved from the rump region, and all mites found on the exposed skin area were removed with forceps and placed in $70 \%$ ethanol. Additionally, the removed fur was stored in $70 \%$ ethanol and was later examined under a stereomicroscope (Olympus ${ }^{\mathrm{TM}}$, Tokyo, Japan), at which time all mites encountered in the sample were collected. Ten specimens of immature, and 20 specimens of mature life-cycle stages of $T$. dixous 
were measured; the mean size (in parentheses) and the range of measurements are given in micrometres $(\mu \mathrm{m})$. No larval stages were recovered, although these were observed within the opisthosoma of some female mites. Identification of nymphs was based on comparison of morphological features with adult females. All specimens were cleared in Hoyer's medium or lactophenol for identification. Morphological terminology is based on Evans and Till (1965) and Domrow (1972, 1987).

Specimens were examined under a Leica ${ }^{\mathrm{TM}}$ (HC) DM 1000 compound microscope, and photographed using a Nikon ${ }^{\mathrm{TM}}$ DS Camera Head DS-5M and a Nikon ${ }^{\mathrm{TM}}$ Camera Control Unit DS-L1. Mites were prepared for scanning electron microscopy by dehydration with ethanol, followed by transfer to hexamethyldisilazane, which was allowed to evaporate. They were then mounted on stubs with double-sided adhesive tape and coated with gold in a Polaron ${ }^{\mathrm{TM}}$ E5000 sputter coater. Photographs were taken with a Phillips ${ }^{\mathrm{TM}} 505$ scanning electron microscope, using digitally acquired images in Spectrum ${ }^{\mathrm{TM}}$.

Voucher specimens of protonymphs, deutonymphs, females and males, have been deposited in the Australian National Insect Collection, CSIRO Division of Entomology, Canberra.

\section{RESULTS}

A total of 4,642 specimens of T. dixous from Trichosurus cunninghami, consisting of 3,950 females, 439 males, 29 protonymphs and 224 deutonymphs, were collected and examined. Additionally, 96 specimens of $T$. crassipes from $T$. vulpecula were examined for comparison. Trichosurolaelaps dixous was the only species of Trichosurolaelaps identified from T. cunninghami, while $T$. crassipes was found only on $T$. vulpecula. The prevalence of $T$. dixous on $T$. cunninghami was greater than 90\% (unpublished data J.H.).

\section{Trichosurolaelaps dixous Domrow, 1972}

T y p e hos t a n d l o c a lity: Trichosurus caninus, Upper Brookfield (Queensland), Australia (Domrow 1972).

\section{Protonymph}

Fig. 1

Poorly sclerotized. Cheliceral segments about three times length of first segment. Single row of 4 deutosternal denticles followed by 1 anterior row of paired denticles. Seta $h_{3}$ longest, with $h_{1}$ and $h_{2}$ about $1 / 3$ its length; cs marginally longer than $h_{1}$. Palpal trochanter with 1 ventral seta and palpal femur apparently lacking al; apotele two-pronged.

Idiosoma 390-475 (403) long; podonotal shield 247279 (268) long, posterior margin trilobed, pygidial shield 60-71 (67) long. Three pairs of mesonotal scutella present. Dorsal chaetotaxy based on that for protonymph of $T$. crassipes (Domrow 1979). Podonotum holotrichous for protonymph, with 16 pairs setae; $j_{4-6}$, $z_{4-5}, s_{4}$ very short. Opisthonotum hypotrichous for protonymph, lacking $J_{3}, Z_{3} ; J_{4}, J_{5}, Z_{4}$ very short. Some setae of J, s/S, r, Z series blade-like (Fig. 1A).
Tritosternum bifid. Sternal shield with 3 pairs of setae; stigmata without recognisable peritremes. Genital setae absent from opisthogaster; $J v_{1-2}$ and $Z v_{2}$ present. $J v_{5}$ marginal. Para-anal setae shorter than post-anal seta.

Coxae II, IV with 1 short spur; 2 spurs on coxae I, III. Anterodistal margin of coxa I with fimbriated edge. $A d_{1}$ on femur I very long, slender (about twice length of femur); $p d_{2}$ of genu I longer than other setae of that segment, about half length of $A d_{1}$. Some distal setae of tarsi I-III elongate, tapered; setae of tarsus IV quite long, stout, especially lateral ones.

\section{Deutonymph}

Figs. 1, 3

More heavily sclerotized than protonymph; but less than in adult. Chelicerae similar to those of protonymph. Deutosternal denticles and hypostomal setae arranged as in protonymph. Ventral seta $\left(v_{2}\right)$ added to palpal trochanter, also third dorsal $\left(d_{3}\right)$ and anterior lateral $(a l)$ seta. Genu apparently with single al. Apotele twopronged.

Idiosoma 507-665 (567) long; dorsal shield entire, 468-539 (491) long and 227-279 (251) wide. Dorsal shield covering most of dorsal idiosoma with little or no lateral indentation. Dorsal chaetotaxy hypotrichous (33 pairs of setae), lacking $j_{3}, r_{1}$ in podonotal portion; $z_{3}$, $s_{1-3}, r_{4}$ added to protonymphal setation. $J_{3}, Z_{3}$ missing in opisthonotal section, $S_{1}$ present. Some dorsal setae $\left(j_{4-6}\right.$, $z_{4-6}, s_{4 ;} J_{1-2}, J_{4-5}, Z_{1-2}, Z_{4}$ ) very short, slender; other setae of marginal opisthonotal series (12-13 pairs) short, blade-like.

Tritosternum bifid, stigmata with short peritremes (length up to twice diameter of stigmata). Para-anal and post-anal setae as in protonymph. Sternal shield with 3 pairs of setae; 1 pair of metasternal setae and 1 pair of genital setae present. Opisthogaster hypertrichous, adding $Z v_{3-5}$ to holotrichous setation (Fig. 1D). Ventral body setae all relatively long, but more marginal opisthogastric setae shorter and blade-like (15 pairs of cuticular setae).

Coxae I-II with 2 spurs, coxa III with 3 spurs; coxa IV with 1 spur. Anterior margin of coxa I as in protonymph. On trochanters I-II, $p v_{1}$ stout spine; $p v_{2}$ elongate, tapered. Anterolateral setae of trochanters I-III thicker, shorter than other setae of segment. Elongate setae on femora I ( $a v)$ and II $\left(a v, p v_{2}\right) . A d_{1}$ (femur I) and $p d_{2}$ (femur II) long, thick, about 1.5 times femoral length. $A v_{1}$ of femur I short, stout spine, similar to $a d_{1-3}$ on genua I-II. $A d_{3}$ (genu I) almost as long as $a d_{1}$ (femur I); $p d_{2}$ (genu II) elongate. In pre-males, $p v$ of tibia I long, setose (Figs. 1D, 3A); in pre-females spinous basally, with setiform elongation (Figs. 1E, 3B). Tarsus I with several long setae; setae of tarsus IV more spinous.

Female

Figs. 2, 3

Cheliceral proportions, deutosternal denticles as in nymphal stages. $h_{3}$ longest hypostomal seta; $h_{2}$ about $1 / 5$ of $h_{3}, h_{1}$ and $c s$ about $1 / 3$ length of $h_{3}$. Palpal setation similar to deutonymph. 

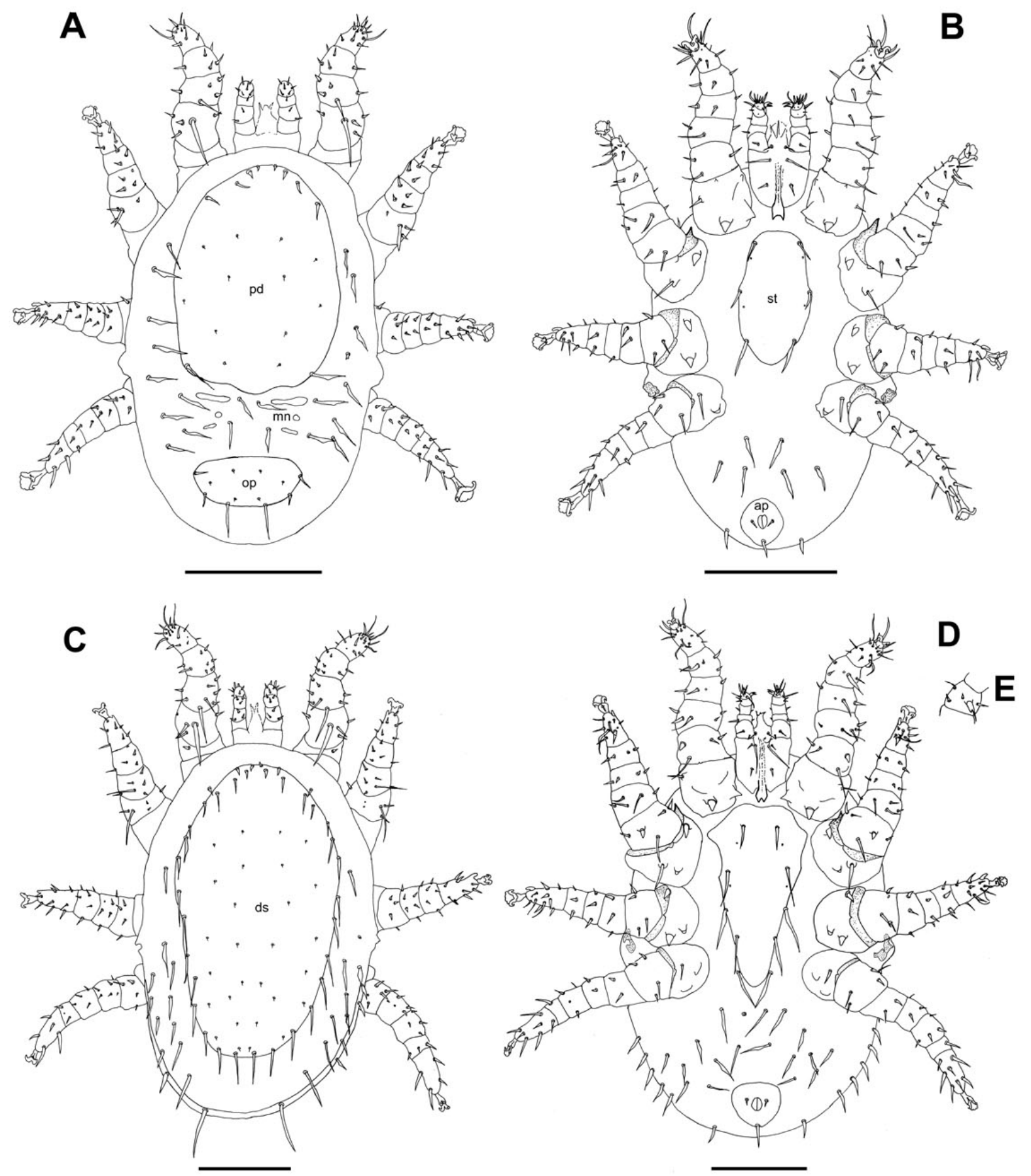

Fig. 1. Trichosurolaelaps dixous, nymphal stages. A - protonymph, dorsal view; B - protonymph, ventral view; C - deutonymph, dorsal view; D - pre-male deutonymph, ventral view; E - pre-female, tibia I, ventral view. Abbreviations: ap - anal plate; ds - dorsal shield; mn - mesonotal scutella; op - opisthonotal shield; pd - podonotal shield; st - sternal shield. Scale bars: $160 \mu \mathrm{m}$.

Idiosoma 598-670 (635) long, dorsal shield large, 533-624 (575) long and 286-325 (307) wide, covering most of body. Dorsal chaetotaxy essentially that of deutonymph, missing $j_{3}, r_{1}, J_{3}, Z_{3}$. Dorsal cuticle with about 14 pairs of setae.

Tritosternum bifid. Sternal shield with 3 pairs of setae, 2 pairs of lyriform fissures; pair of metasternal setae on metasternal shields, latter fused with endopodal shield of coxa III. Sternal shield not reticulate; subrectangular, anterior and posterior margins convex, latter about 2/3 along coxa III. Genital shield flask-shaped, with 1 pair of genital setae and well-developed hyaline flap, covering about $2 / 3$ of sternal shield anteriorly. Para-anal and post-anal setae as for deutonymph, on 


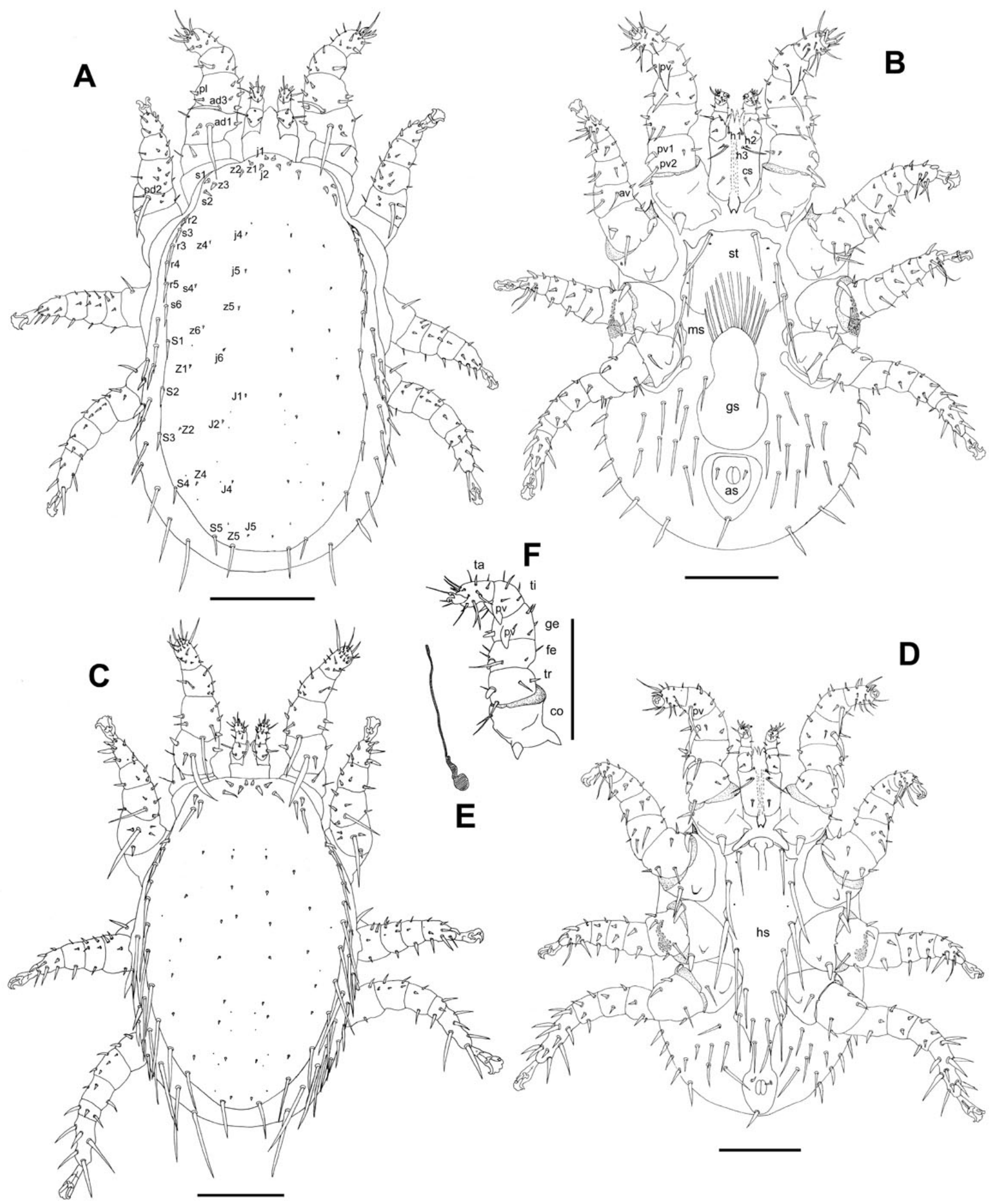

Fig. 2. A-D. Trichosurolaelaps dixous, adult. A - female, dorsal view; B - female, ventral view; C - male, dorsal view; D male, ventral view. E-F. Trichosurolaelaps crassipes, female. E - peritreme; F - leg I, ventral view. Abbreviations: as - anal shield; co - coxa; fe - femur; ge - genu; gs - genital shield; hs - holoventral shield; ms - metasternal shield; st - sternal shield; ta - tarsus; ti - tibia; tr - trochanter. Setation of female dorsal shield and key leg setation is also labelled according to Evans and Till (1965) and Domrow (1972). Scale bars: $160 \mu \mathrm{m}$. 

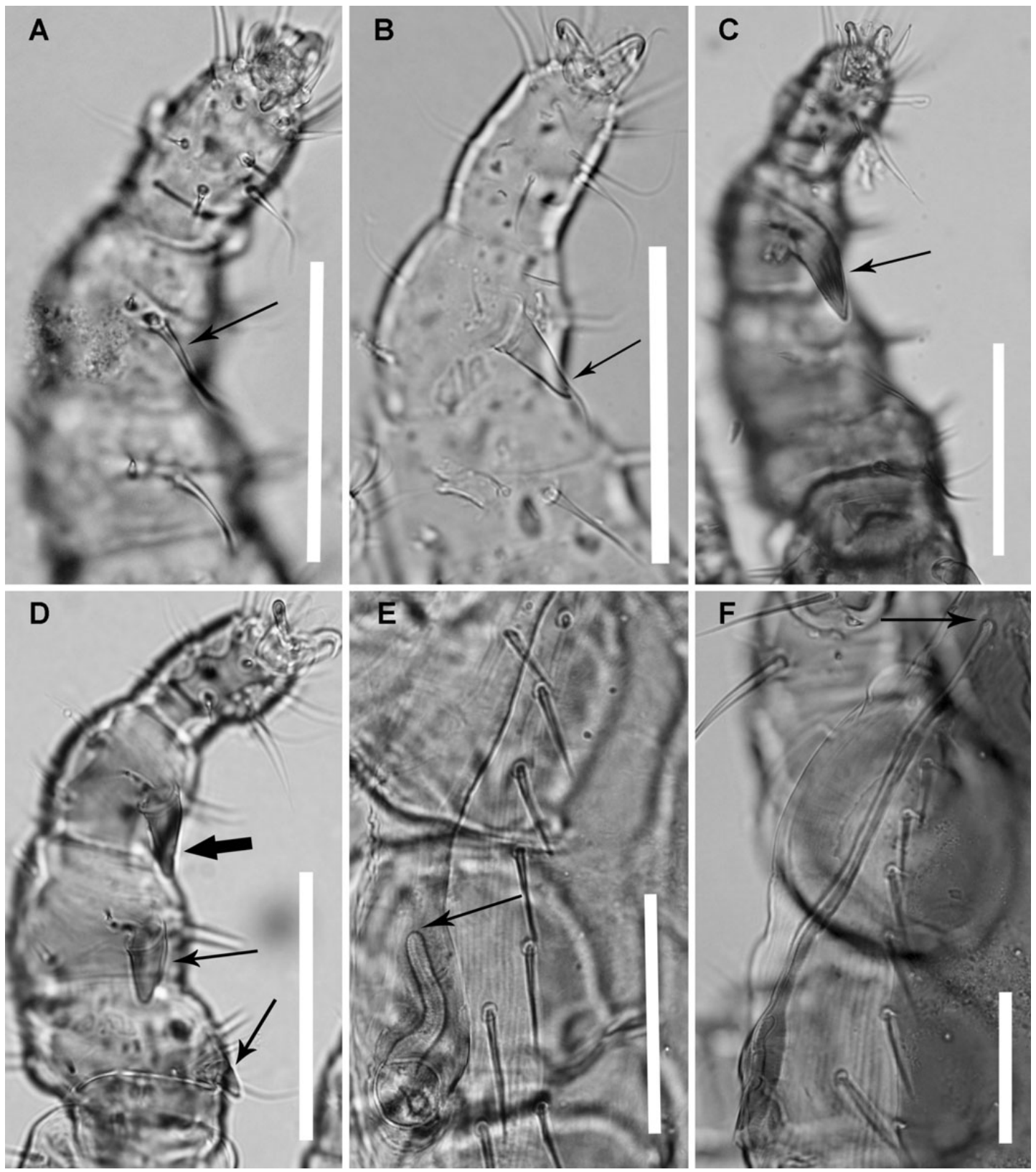

Fig. 3. Light micrographs of Trichosurolaelaps dixous and $T$. crassipes. $\mathbf{A}-T$. dixous, pre-male deutonymph, ventral view of leg I, note $p v$ (arrow) of tibia; $\mathbf{B}-T$. dixous, pre-female deutonymph, ventral view of leg I, note $p v$ of tibia spinous basally with setiform elongation (arrow); $\mathbf{C}-T$. dixous, female, ventral view of leg I, note $p v$ (arrow) of tibia; $\mathbf{D}-T$. crassipes, female, ventral view of leg I, note $p v$ of tibia (fat arrow), genu and femur (thin arrows); $\mathbf{E}-T$. dixous, female, dorsal view of peritreme, note peritreme does not extend beyond anterior margin of coxa III (arrow); F - T. crassipes, female, dorsal view of peritreme, note narrow elongation of peritreme to coxa I (arrow). Scale bars: $100 \mu \mathrm{m}$.

subtriangular anal shield. Metapodal shields not obvious; peritremes as in deutonymph, not extending beyond coxa III (Figs. 2B, 3E). Ventral cuticle with about 16 pairs of setae.

All coxae with strongly developed spurs: coxae I-II with 2 spurs, coxa III with 3 spurs, coxa IV with one robust and one less robust spur. Anterior spurs of coxae II-III directed posteriorly, somewhat longer, slimmer than remainder. Anterodistal margin of coxa I as in nymphs. Trochanters I-II with stout spines $\left(p v_{1}\right)$; at least one strong small spine $(p l)$ on femur I, genu I, tibia I. Tibia I with large ventral, posteriorly-directed spur $(p v)$, of similar length as tibial segment, about $1 / 3$ its width (Figs. 2B, 3C). Dorsal setation on legs I-II same as deutonymphs, except $p d_{2}$ on genu II not elongated. Setae of tarsus IV long and spiniform. 
Male

Figs. 2, 3

Capitulum as for female except for presence of spermatodactyl.

Idiosoma 475-683 (572) long, dorsal shield large, 462-663 (553) long and 254-410, (318) wide, covering most of body. Dorsal chaetotaxy as in female, but with about 12-13 pairs of setae on dorsal cuticle.

Tritosternum bifid. Holoventral shield narrowing to pass between coxae IV before expanding slightly upon reaching opisthogaster, then tapering before reaching anal shield (fused to holoventral shield). Holoventral shield with 8 pairs of elongate setae, extending past origin of next seta, anal portion of shield with 1 pair of para-anal setae and 1 post-anal seta, as in female. Anterior margin of shield convex; shield with reticulate pattern, extending posteriorly to about level of coxae IV. Peritremes as in female, ventral cuticle with about 12 pairs of setae, most marginal shorter.

Coxae as for female, except posterior spur on coxa IV much less pronounced. For leg I, $p v_{1}$ of trochanter, femur and genu spur-like; those of femur and genu especially long and tapered. $P v$ of tibia I elongate and tapered, about twice length of that in female, not robust and spur-like. Dorsal chaetotaxy of legs I-II similar to female, except $p d_{2}$ on genu II elongate as in deutonymph. Tarsal setae as in female.

\section{DISCUSSION}

Descriptions of all life-cycle stages of Trichosurolaelaps crassipes have been published (Womersley 1956, Domrow 1979). However, only the adult stages of Trichosurolaelaps dixous have been described previously (Domrow 1972, 1987). A comparison of the results presented here with existing descriptions of T. crassipes (Domrow 1979, Clark 1995) indicate that there are few, if any, morphological differences, other than size, between the protonymphal stages of $T$. dixous and $T$. crassipes. Idiosomal length of $T$. dixous protonymphs was 390-475 $\mu \mathrm{m}$, compared to 310-340 $\mu \mathrm{m}$ (Domrow 1979) and 250-300 $\mu \mathrm{m}$ (Clark 1995) for T. crassipes. Size differences also exist between the deutonymphal stages of the two species: idiosomal length is 507-665 $\mu \mathrm{m}$ in $T$. dixous, compared to 450 $460 \mu \mathrm{m}$ (Domrow 1979) and approximately $470 \mu \mathrm{m}$ (Clark 1995) in T. crassipes. In the deutonymphal stages of $T$. crassipes, pre-males can be differentiated from pre-females by variation in the shape of $a v_{2}$ on genu I and tibia I (Domrow 1979). The same variation exists in $T$. dixous, described here for $p v$, but is present only on tibia I. Thus, while pre-female $T$. crassipes deutonymphs have a seta which is proximally spiniform but distally narrows with a short setose elongation on both genu I and tibia I; pre-female $T$. dixous deutonymphs have this feature only on tibia I. This mirrors the differences in leg I setation between the adult female mites of the two species and permits differentiation between pre- female, but not male, deutonymphs of $T$. dixous and T. crassipes.

Differences in setation of leg I are also a reliable and easy means of differentiating adult female $T$. dixous and $T$. crassipes. While $T$. dixous females have one strong ventral tibial spur on each first leg (Figs. 2B, 3C), T. crassipes females, as observed on the specimens collected as part of this study, have a slightly smaller tibial spur, which is accompanied by a similar spur on the ventral aspect of genu I (Figs. 2F, 3D). Additionally, $T$. crassipes females have a stout, posteriorly-directed spine $(p v)$ on femur I and trochanter I, whereas T. dixous females only have such a spine on trochanter I. Another distinguishing feature, but often more difficult to visualise, is the extension of the peritreme (with a much reduced diameter compared to its initial section) to near coxa I in female, but not male, T. crassipes (see Figs. 3E, 3F) (Domrow 1972, 1987).

The size differences between nymphs of the two species are similar to the trend seen in the adult life-cycle stages. Female $T$. crassipes range in idiosomal length 470-560 $\mu \mathrm{m}$ and males 380-500 $\mu \mathrm{m}$ (Domrow 1972, 1987). In the specimens measured, idiosomal length of female $T$. dixous varied $598-670 \mu \mathrm{m}$, slightly smaller than the 650-700 $\mu \mathrm{m}$ described for females of this species by Domrow (1972). There was great variation in idiosomal length of $T$. dixous males $(475-683 \mu \mathrm{m})$, especially since the males described by Domrow (1972) showed much less variation $(640-660 \mu \mathrm{m} ; \mathrm{n}=4)$. No reliable morphological features to distinguish $T$. dixous males from those of $T$. crassipes could be found in the specimens collected here, and so it is possible that some of the smaller males were misidentified and were in fact T. crassipes. However, all male mites identified as T. dixous were collected from Trichosurus cunninghami. As all female specimens of Trichosurolaelaps found on T. cunninghami were identified unequivocally as $T$. dixous, it would be surprising to find male $T$. crassipes, but not females, on the same host.

Trichosurolaelaps crassipes has been reported at relatively high prevalences from $T$. cunninghami (Viggers 1996) and Trichosurus caninus (Domrow 1972, Presidente et al. 1982, Viggers 1996). However, in the population at Boho South, although commonly found on Trichosurus vulpecula, T. crassipes was never found to infest the sympatric population of $T$. cunninghami. While it is possible that the species was not collected from $T$. cunninghami despite it being present, given the large number of specimens of Trichosurolaelaps collected and examined from T. cunninghami as part of this study, it seems unlikely that $T$. crassipes was overlooked, had it occurred in significant numbers. It is possible that some $T$. crassipes mites were misidentified as $T$. dixous. However, this also seems unlikely as every single mite collected was examined carefully. There may be little opportunity for $T$. crassipes to be transmitted from $T$. vulpecula to $T$. cunninghami at our study 
site. Although trapping data indicate that the two possum species are sympatric at Boho South, we have little knowledge of the degree to which they share resources, such as dens. Viggers (1996) did not examine T. vulpecula in her study, so it is not clear whether there was any overlap between the two possum species at her study sites. Finally, it is possible that $T$. crassipes recovered from T. vulpecula at Boho South is genetically different to $T$. crassipes identified from $T$. cunninghami at other locations (Viggers 1996, Viggers et al. 1998) and has different host preferences. This is supported by at least one morphological difference between $T$. crassipes collected from T. caninus and T. vulpecula. Domrow (1972) noted that $T$. crassipes from $T$. caninus had one fewer pair of setae on their dorsal shield ( $J_{2}$ missing) than those from $T$. vulpecula. The specimens of $T$. crassipes collected from T. vulpecula at Boho South all had $J_{2}$ present. It is therefore possible that this form of $T$. crassipes is specific for $T$. vulpecula and does not infect $T$. cunninghami. The form which infects both T. caninus and T. cunninghami may not occur at Boho South.

There are many similarities between the life-cycle stages of the two congeneric species $T$. dixous and
T. crassipes. Generally speaking, specimens of $T$. dixous are larger than $T$. crassipes, but overlap in sizes may occur and size is therefore not always a reliable differentiating feature. Protonymphal and male life-cycle stages of the two species appear to differ only in size. However, variation in leg morphology allows reliable differentiation of pre-female deutonymphs and females. Trichosurolaelaps dixous was only recovered from T. cunninghami and never from T. vulpecula, which is consistent with other host records for this mite species (Viggers and Spratt 1995). However, in the present study, T. crassipes also appeared to be highly host specific, being found on $T$. vulpecula, but never recovered from $T$. cunninghami, a finding in contrast to previous studies (Viggers 1996, Viggers et al. 1998).

Acknowledgements. Jasmin Hufschmid was supported by an Australian Postgraduate Award and the research was financially supported by the Holsworth Wildlife Research Endowment. Trapping of possums and sample collection was approved by The University of Melbourne Animal Ethics Committee, permit Nos. 02052 and 05064, and the Victorian Department of Sustainability and Environment Research Permit Nos. 10001937 and 10003306.

\section{REFERENCES}

BenNetT A.F., LuMSDEN L.F., ALEXANDER J.S., DunCAN P.E., JOHNSON P.G., ROBERTSON P., SILVEIRA C.E. 1991: Habitat use by arboreal mammals along an environmental gradient in north-eastern Victoria. Wildl. Res. 18: 125-146.

CLARK J. 1993: Towards better pelts from possums: mite fauna of Trichosurus vulpecula. N. Z. Entomol. 16: 84-90.

CLARK J. 1995: Morphological and life-cycle aspects of the parasitic mite Trichosurolaelaps crassipes Womersley, 1956, of trichosurid possums. N. Z. Vet. J. 43: 209-214.

DomRow R. 1972: The crassipes species-group, genus Trichosurolaelaps Womersley (Acari: Dermanyssidae). J. Aust. Entomol. Soc. 11: 295-305.

DoMROW R. 1979: Some dermanyssid mites (Acari), mostly from Australasian rodents. Proc. Linn. Soc. N. S. Wales 103: 189208.

DomRow R. 1987: Acari Mesostigmata parasitic on Australian vertebrates: an annotated checklist, keys and bibliography. Invertebr. Taxon. 1: 817-948.

Evans G., TILL W. 1965: Studies on the British Dermanyssidae (Acari: Mesostigmata). Bull. Br. Mus. (Nat. Hist.) Zool. 13: 249-293.

Hemsley S., CANField P. 1994: Dermatitis in free-living common brushtail possums (Trichosurus vulpecula). Aust. Vet. Pract. 24: 147-155.

Kerle J.A., MCKay G.M., Sharman G.B. 1991: A systematic analysis of the brushtail possum, Trichosurus vulpecula (Kerr, 1792) (Marsupialia, Phalangeridae). Aust. J. Zool. 39: 313331.

MUNDAY B. 1966: Diseases of Tasmania's free-living animals Tasmanian Department of Agricultural Research Bulletin. 5: $1-29$.
PRACY L. 1962: Introduction and liberation of the opossum (Trichosurus vulpecula) into New Zealand. New Zealand Forest Service Information Series, No. 45, 28 pp.

PRESIDENTE P. 1978: Diseases seen in free-ranging marsupials and those held in captivity. In: J.D. Stewart Refresher Course for Veterinarians, Fauna - Part B. Postgraduate Committee in Veterinary Science, University of Sydney, 36, pp. 457-471.

PRESIDENTE P. 1984: Parasites and diseases of brushtail possums. In: A. Smith and I. Hume (Eds.), Possums and Gliders. Australian Mammal Society, Sydney, pp. 171-187.

PRESIDENTE P., BARNETT J., HOW R., HUMPHREYS W. 1982: Effects of habitat, host sex and age on the parasites of Trichosurus caninus (Marsupialia: Phalangeridae) in north-eastern New South Wales. Aust. J. Zool. 30: 33-47.

SWEATMAN G. 1962: Parasitic mites of non-domesticated animals in New Zealand. N. Z. Entomol. 3: 15-23.

VAN DER REE R., WARD S.J., HANDASYDE K.A. 2004: Distribution and conservation status of possums and gliders in Victoria. In: R.L. Goldingay and S.M. Jackson (Eds.), The Biology of Australian Possums and Gliders. Surrey Beatty \& Sons, Chipping Norton, N.S.W., pp. 91-110.

VIGGERS K.L. 1996: Assessment of health, condition and the effects of parasites in the mountain brushtail possum. PhD Thesis. Australian National University, Canberra, 264 pp.

VigGERS K.L., LiNDENMAYER D.B. 2004: A review of the biology of the short-eared possum Trichosurus caninus and the mountain brushtail possum Trichosurus cunninghami. In: R. Goldingay and S. Jackson (Eds.), The Biology of Australian Possums and Gliders. Surrey Beatty and Sons, Chipping Norton, pp. 490-505. 
Viggers K.L., LinDENMAYER D.B., CUNNINGHAM R.B., DONNELLY C.F. 1998: The effects of parasites on a wild population of the mountain brushtail possum (Trichosurus caninus) in south-eastern Australia. Int. J. Parasitol. 28: 747-755.

Received 16 April 2008
VIGGERS K.L., SPRATT D.M. 1995: The parasites recorded from Trichosurus species (Marsupialia: Phalangeridae). Wildl. Res. 22: 311-332.

WOMERSLEY H. 1956: On some new Acarina Mesostigmata from Australia, New Zealand and New Guinea. J. Linn. Soc. Lond. (Zool.) 42: 505-599.

Accepted 12 August 2008 